\title{
Institutional analysis
}

\section{Graham Epstein, ${ }^{1}$ Sergio Villamayor-Tomas ${ }^{2}$ and Michael Schoon ${ }^{3}$}

${ }^{1}$ SCHOOL OF POLITICS, SECURITY, AND INTERNATIONAL AFFAIRS, UNIVERSITY OF CENTRAL FLORIDA, FLORIDA, USA

${ }^{2}$ INSTITUTE OF ENVIRONMENTAL SCIENCE AND TECHNOLOGY, AUTONOMOUS UNIVERSITY

OF BARCELONA, BARCELONA, SPAIN

${ }^{3}$ SCHOOL OF SUSTAINABILITY, ARIZONA STATE UNIVERSITY, TEMPE, ARIZONA, USA

\section{Key methods discussed in this chapter}

Institutional analysis and development framework, SES framework, action situations, networks of action situations, institutional grammar tool, rule typology

\section{Connections to other chapters}

Institutional analysis relies on other methods to assess the institutions being studied. Frequently, this entails interviews and participant observation (Chapter 7) and comparative case study analysis (Chapter 20). While many of the methodological approaches in this book could be used in conjunction with institutional analysis, a few other commonly featured approaches include behavioural experiments (Chapter 21), network analysis (Chapter 23) and agent-based modelling (Chapter 28).

\section{Introduction}

Institutional analysis is a term that is shared by a number of different intellectual traditions, including the Bloomington or Ostrom School of Institutional Analysis, which is the focus of this chapter. Readers interested in situating the Bloomington School within the broader discourse on institutions should refer to Hall and Taylor (1996) and Mitchell (1988). For other overviews on institutions and institutions and the environment, see also Hodgson (1998) and Vatn (2005).

Institutional analysis has rapidly gained traction as a leading interdisciplinary approach for analysing the structure of social-ecological problems and developing institutional solutions to address them (Van Laerhoven and Ostrom 2007). It emerged from the field of public administration where administrative consolidation and centralisation were promoted as a panacea for the problem of delivering public services in metropolitan areas based on a general assumption that all public services exhibited economies of scale. Institutional analysis was used to demonstrate the folly of these assumptions, highlighting a range of factors that may mediate the impacts of scale on the costs and benefits associated with different public goods and services (Ostrom, Tiebout, and Warren 1961; Ostrom, Parks, and Gordon 1973). 


\begin{tabular}{|c|c|}
\hline \multicolumn{2}{|c|}{ SUMMARY TABLE: INSTITUTIONAL ANALYSIS } \\
\hline DISCIPLINARY BACKGROUND & KNOWLEDGE TYPE \\
\hline $\begin{array}{l}\text { The methods in this chapter are derived } \\
\text { from or have most commonly been used in: } \\
\text { Political Science, Human Geography, } \\
\text { Interdisciplinary }\end{array}$ & $\begin{array}{l}\text { The methods in this chapter are primarily } \\
\text { used to generate the following types of } \\
\text { knowledge: } \\
\text { - Descriptive } \\
\text { - Exploratory } \\
\text { - Explanatory }\end{array}$ \\
\hline RESEARCH APPROACH & PURPOSE OF METHOD \\
\hline $\begin{array}{l}\text { The methods in this chapter originate } \\
\text { from or most commonly adopt the } \\
\text { following research approaches: } \\
\text { - Analytical/objective }\end{array}$ & $\begin{array}{l}\text { The most common purposes of using the } \\
\text { methods in this chapter are: } \\
\text { - System understanding }\end{array}$ \\
\hline TEMPORAL DIMENSION & SYSTEMIC FEATURES AND PROCESSES \\
\hline $\begin{array}{l}\text { The methods in this chapter are most } \\
\text { commonly applied to the following } \\
\text { temporal dimensions: } \\
\text { - Present (typically within the last } \\
\text { 5-10 years) } \\
\text { - Recent past (post-1700s) }\end{array}$ & \multirow[t]{3}{*}{$\begin{array}{l}\text { While most methods can do many } \\
\text { things, the methods in this chapter are } \\
\text { particularly good (i.e. go-to methods) for } \\
\text { addressing the following: } \\
\text { - SES components and linkages } \\
\text { - Collective action and collaborative } \\
\text { governance }\end{array}$} \\
\hline SPATIAL DIMENSION & \\
\hline $\begin{array}{l}\text { The methods in this chapter are primarily } \\
\text { either or both: } \\
\text { - Non-spatial } \\
\text { The methods in this chapter are most } \\
\text { commonly applied at the following } \\
\text { spatial scales: } \\
\text { - Local } \\
\text { - Multiple places/sites around the world }\end{array}$ & \\
\hline
\end{tabular}


A similar logic, meanwhile, prevailed in the context of natural resource management, where Hardin's (1968) tragedy of the commons narrative proclaimed that society was destined for ruin in the absence of enforceable private property rights or strong central government command and control. Elinor Ostrom's (1990) Governing the Commons convincingly refuted this narrative and identified the institutional foundations of sustainable community-based natural resource management, which continue to enjoy considerable empirical support (Cox, Arnold, and Villamayor-Tomas 2010; Baggio et al. 2016). This chapter therefore provides an overview of the institutional analysis and development and social-ecological systems (SES) frameworks that have been used to develop, organise and undertake highly influential and impactful research on SES over the past 30 years.

Institutional analysis is oriented around the role of institutions in shaping the incentives, opportunities and constraints that actors face as they interact with the environment and one another. However, unlike many branches of institutional analysis (see Shepsle 2006), Ostrom's frameworks tend to reject the notion of the all-knowing and calculative rational optimiser in favour of a model of bounded rationality in which actors are presumed to be goal-seeking but rely upon heuristics, such as satisficing, in order to make complex and time-sensitive decisions (Ostrom 1998). Institutions, which are defined broadly to include formal and informal rules, norms and shared strategies (Crawford and Ostrom 1995), play a particularly important role in decision-making and the subsequent social and ecological outcomes that are realised. Boundary rules that define the eligibility of actors to harvest resources, for instance, can provide powerful incentives to invest in the management and sustainable exploitation of resources by internalising the costs and benefits of resource use (Ostrom 1990).

Although institutions are, unsurprisingly, central to institutional analysis, attributes of communities (e.g. group size, cultural homogeneity, economic status) and resources (e.g. clarity of boundaries, spatial distribution, mobility) also play an important role in influencing the decisions that actors make and the outcomes that are observed (Agrawal 2003; Ostrom 2005 , 2007). Indeed, institutional analysis is defined to a great extent by its attentiveness to a large number of attributes of actors, institutions and the environment that potentially influence the sustainability of SES, as shown in the institutional analysis and development framework illustrated in Figure 22.1.

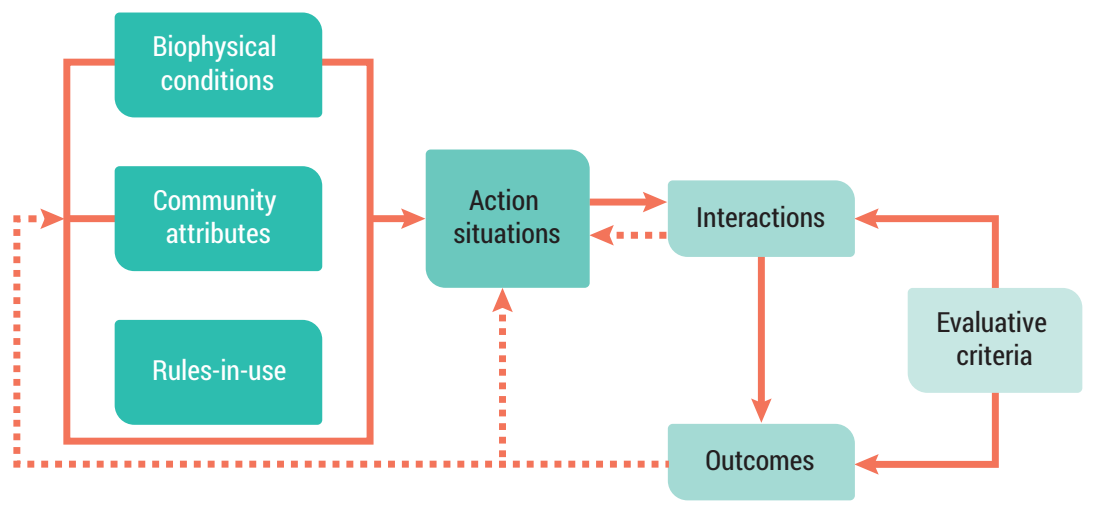

Figure 22.1 The institutional analysis and development framework (Ostrom, Gardner and Walker 1994, 37) 


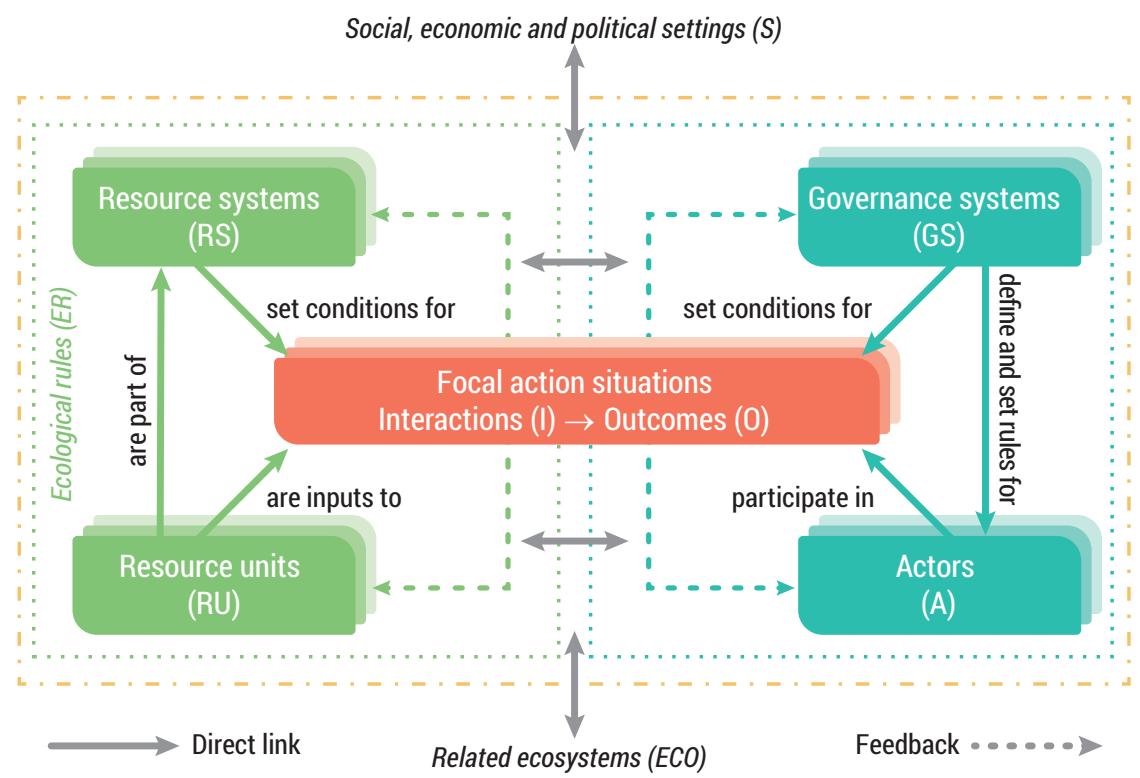

Figure 22.2 The SES framework (Monroy-Sais et al. 2016)

The institutional analysis and development (IAD) and SES frameworks are the primary tools with which institutional analysts approach and undertake research on decision-making and the sustainability of SES. The IAD framework was developed as a general tool for conducting research on the development and impacts of institutions in a range of empirical settings (Kiser and Ostrom 1982; Ostrom 2005); while the SES framework, shown in Figure 22.2, was developed to provide a better understanding of how different configurations of social, ecological and institutional factors affect the sustainability of SES, and to facilitate comparisons (Ostrom 2005, 2007; McGinnis and Ostrom 2014). Although the frameworks differ in terms of their respective levels of detail and the ways in which they tend to be applied in research, they are both organised around the study of one or more action situations in which actors make decisions and generate outcomes. Action situations can be broadly understood as spaces of interdependent decision-making (individuals make decisions that generate positive and negative externalities) (Ostrom, Gardner, and Walker 1994).

Environmental governance invariably involves a large number of potentially salient action situations pertaining to tasks such as resource use, infrastructure maintenance, rulemaking, social and environmental monitoring, sanctioning and conflict resolution (McGinnis 2011). Whereas applications of the IAD framework tend to be more attentive to the analysis of dynamics across networks of interrelated action situations (McGinnis 2011; Villamayor-Tomas et al. 2015), applications of the SES framework tend to neglect the underlying processes to focus on associations between variables and social-ecological outcomes (Gutierrez, Hilborn, and Defeo 2011). Nonetheless, there is nothing that would preclude an analyst from analysing networks of action situations with the SES framework, or from using the IAD framework to develop insights concerning the social, ecological and institutional correlates of environmental sustainability (Cole, Epstein, and McGinnis 2019). Indeed, both frameworks operate under the general hypothesis that decisions in action situations are influenced by the incentives, opportunities and constraints that actors face, which are in turn determined by the institutions that 
apply to each action situation as well as other attributes of the broader social, ecological and institutional context in which decisions are made.

Other longstanding developments within the 'family of IAD tools' (McGinnis 2011) include the institutional grammar tool, which has been used to carry formal analyses of institutions and the networks of rights and responsibilities they generate (Crawford and Ostrom 1995); and the 'levels of action' distinction, which facilitates the study of institutions operating at different levels of individual and collective decision-making (Kiser and Ostrom 1982). Others, meanwhile, have extended these frameworks to address gaps or specific types of research questions. These include the robustness framework, which provides a heuristic to study interactions among SES components (Anderies, Janssen, and Ostrom 2004); the nature-related transactions framework, which draws attention to the characteristics of the interdependencies generated around the joint use of natural resources (Hagedorn 2008); and the politicised IAD framework, which focuses on the role of discourses and the broader political-economic context in shaping interactions and outcomes in action situations (Clement 2010).

\section{SES problems and questions}

Institutional analysis is generally promoted as an interdisciplinary approach for developing, organising and undertaking research on collective action and environmental sustainability in heterogeneous social and ecological contexts (Ostrom 2005; Poteete, Janssen, and Ostrom 2010). This has resulted in the development of several tools that facilitate research on institutions and their role in SES, as briefly outlined in Table 22.1. The utility of institutional analysis is clearly demonstrated by applications across a wide range of environmental issues, including forests, fisheries, irrigation and rangelands (see Partelow 2018); methods, including case studies, experiments and statistical analysis (see Poteete, Janssen, and Ostrom 2010); and levels of analysis, ranging from the study of individuals to the study of global environmental regimes (Ostrom, Gardner, and Walker 1994; Fleischman et al. 2014). Nonetheless, its most significant contributions to SES theory and practice relate to questions concerning (a) the institutional foundations of sustainable environmental governance regimes, (b) the micro-foundations of cooperative behaviour in resource-dependent communities, and (c) the implications of different social and ecological contexts for institutional design (see also Chapter 10 in Poteete, Janssen and Ostrom 2010 for an overview on the theory generated around these three questions).

Expanding on the points above, first, institutional analysis of SES has been defined to a great extent by Elinor Ostrom's (1990) institutional design principles, which emerged from an empirical analysis of several cases of community-based natural resource management. The primacy of knowledge from empirical research is, in fact, a defining characteristic of institutional analysis, stemming from concerns about the inappropriate use of abstracted theories and models in environmental policy and planning (Schlager 1999). Noteworthy contributions from applications of the design principles to SES theory include highlighting the general importance of participation in rulemaking, social monitoring and adjusting institutional arrangements to fit the contexts in which they are used (Ostrom 1990; Agrawal 2003; Cox, Arnold, Villamayor-Tomas 2010; Baggio et al. 2016).

Second, research on the micro-foundation of cooperative behaviour, meanwhile, seeks to better understand the conditions in which actors are more (or less) likely to cooperate, relying on case studies and ethnographic research, common-pool resource experiments and other methodological approaches highlighted below and discussed in other chapters on behavioural 
experiments (Chapter 21), interviews (Chapter 7) and case study analysis (Chapter 20), among others. This research has offered an important counterpoint to rational choice theory by clearly demonstrating that institutional arrangements that support endogenous rule choice, such as communication and voting, and/or allow participants to sanction one another, can yield high levels of cooperation in both laboratory and field settings (Ostrom, Gardner, and Walker 1994; Cárdenas, Stranlund, and Willis 2000; Janssen et al. 2010; DeCaro, Janssen, and Lee 2015). Although insights from laboratory (lab) experiments, as discussed in the chapter on behavioural experiments (Chapter 21), enjoy strong internal validity, important questions remain concerning the extent to which they reflect essential features of the resource use and management problems experienced by communities as identified in the case studies. Researchers have begun to test these questions through field experiments as well. As a result, scholars are increasingly shifting their attention towards understanding the implications of different social and ecological characteristics for cooperation and institutional design, including resource dynamics (Janssen et al. 2010), thresholds and regime shifts (Schill, Lindahl, and Crépin 2015), interlinked resources (Lindahl, Bodin, and Tengö 2015), uncertainty (Janssen 2013) and past experience with successful self-organisation (Gelcich et al. 2013).

Lastly, with reference to environmental governance, institutional analysis is frequently used to address questions concerning the fit between institutions and the broader social, ecological and institutional context in which they are found (Young 2002; Galaz et al. 2008; Epstein et al. 2015). Indeed, the concept of contingency is a recurrent theme in the scholarship of Vincent and Elinor Ostrom (Dietz 2005), urging scholars and decision-makers to attend carefully to the structure of problems when developing institutional arrangements to address them. Participatory rulemaking is often recommended as a general strategy to improve the fit of institutions by providing mechanisms for incorporating knowledge of the local context (Chhatre and Agrawal 2009). Others, meanwhile, have examined the fit between institutions and local contexts by considering how variability in the attributes of communities such as group size (Agrawal and Goyal 2001) and inequality (Andersson and Agrawal 2011), and resource attributes such as mobility and storage (Schlager, Blomquist, and Tang 1994) influence the efficacy of alternative institutional arrangements. More recently, social-ecological networks have been used to highlight the importance of consolidating governance functions or establishing governance networks to coordinate the management of interlinked resources (Bodin 2017).

Table 22.1 Summary of key approaches used in institutional analysis

\begin{tabular}{lll}
\hline Main approach & Description & References \\
\hline Institutional & An institutional analysis and development (IAD) & Key introductory text \\
$\begin{array}{l}\text { analysis and } \\
\text { development }\end{array}$ & framework is a structured approach used to & Ostrom 2005 \\
framework & community, rules-in-use and biophysical conditions Applications to SES & Ostrom 1990; \\
& structure interactions in action situations to & Gibson, McKean, and \\
& generate outcomes. & Ostrom 2000 \\
& Methods & \\
& Single case studies, comparative case studies, \\
& process tracing, statistical analysis, meta-analysis & \\
\hline
\end{tabular}




\begin{tabular}{|c|c|c|}
\hline Main approach & Description & References \\
\hline SES framework & $\begin{array}{l}\text { An SES framework is a diagnostic approach used to } \\
\text { investigate the combinations of social, ecological } \\
\text { and institutional factors that contribute to social } \\
\text { and environmental outcomes. } \\
\text { Methods } \\
\text { Single case studies, comparative case studies, } \\
\text { process tracing, statistical analysis, meta-analysis }\end{array}$ & $\begin{array}{l}\text { Key introductory text } \\
\text { Ostrom } 2007 \\
\text { Applications to SES } \\
\text { Basurto and Ostrom 2009; } \\
\text { Gutierrez, Hilborn, and } \\
\text { Defeo } 2011\end{array}$ \\
\hline Action situations & $\begin{array}{l}\text { Action situations are an approach used to develop } \\
\text { and test models of decision-making through } \\
\text { manipulation of rules (i.e. communication, } \\
\text { sanctioning) that structure interactions. } \\
\text { Methods } \\
\text { Laboratory experiments, field experiments, agent- } \\
\text { based models }\end{array}$ & $\begin{array}{l}\text { Key introductory text } \\
\text { Ostrom } 2005 \\
\text { Applications to SES } \\
\text { Ostrom, Gardner, and } \\
\text { Walker 1994; } \\
\text { Anderies 2000; } \\
\text { Cárdenas and Ostrom } 2004\end{array}$ \\
\hline $\begin{array}{l}\text { Networks of } \\
\text { action situations }\end{array}$ & $\begin{array}{l}\text { Networks of action situations are an approach } \\
\text { used to analyse decision-making processes across } \\
\text { systems of linked action situations that jointly } \\
\text { influence outcomes. } \\
\text { Methods } \\
\text { Single case studies, comparative case studies, } \\
\text { process tracing }\end{array}$ & $\begin{array}{l}\text { Key introductory text } \\
\text { McGinnis } 2011 \\
\text { Applications to SES } \\
\text { Villamayor-Tomas et al. 2015; } \\
\text { Jones, Rigg, and } \\
\text { Pinkerton 2017; } \\
\text { McCord et al. } 2017\end{array}$ \\
\hline $\begin{array}{l}\text { Institutional } \\
\text { grammar tool }\end{array}$ & $\begin{array}{l}\text { The institutional grammar tool is a systematic } \\
\text { approach used to characterise the design of } \\
\text { institutional arrangements to facilitate analysis } \\
\text { of formal institutions, their change and their } \\
\text { interlinkages. } \\
\text { Methods } \\
\text { Single case studies, comparative case studies, } \\
\text { process tracing, statistical analysis, meta-analysis }\end{array}$ & $\begin{array}{l}\text { Key introductory texts } \\
\text { Crawford and Ostrom 1995; } \\
\text { Siddiki et al. } 2011 \\
\text { Applications to SES } \\
\text { Siddiki, Basurto, and } \\
\text { Weible 2012; } \\
\text { Heikkila and Weible 2018; } \\
\text { Lien, Schlager, and } \\
\text { Lona } 2018\end{array}$ \\
\hline Rule typology & $\begin{array}{l}\text { Rule typology is a systematic approach used to } \\
\text { feature institutional configurations as they affect } \\
\text { behaviour in action situations and change over } \\
\text { time. }\end{array}$ & $\begin{array}{l}\text { Key introductory text } \\
\text { Crawford and Ostrom } 2005 \\
\text { Applications to SES } \\
\text { Ostrom and Basurto 2011; } \\
\text { Villamayor-Tomas et al. 2015 }\end{array}$ \\
\hline
\end{tabular}

Table 22.1 highlights several approaches, tools and frameworks commonly used in institutional analysis and the methods used in conjunction with them. Key references and application to the study of SES are also given.

\section{Limitations}

Despite being promoted as a flexible and widely applicable tool for empirical research on environmental sustainability, institutional analysis is often applied to a relatively limited range 
of cases, problems and outcomes. The vast majority of cases that inform institutional theory, for instance, are framed in terms of local communities exploiting a single common-pool resource, relatively isolated from the broader social, ecological and institutional context in which they are found (Agrawal 2003). Although this greatly enhances the tractability of research, it also neglects critical interactions among resources and across scales that may drive resource outcomes at local, regional or even global scales. The sustainability of a resource, for instance, often depends on the management of other related resources, such as predator and prey species as well as inputs of water and energy for food production (Bodin et al. 2014). Similarly, efforts to manage local resources are often challenged by connections to global markets that can rapidly overwhelm the capacity of local communities to respond effectively (Berkes et al. 2006).

A further challenge stems from the early empirical foundations of institutional research which focused on understanding institutional robustness, or more generally the attributes of institutions that allow them to persist, promote long-term cooperation and avoid overexploitation of resources (Ostrom 1990; Anderies, Janssen, and Ostrom 2004). This has allowed scholars to rapidly develop a general understanding of the institutional ingredients for longterm sustainable community-based management, but with little guidance about the underlying processes through and conditions in which those institutions emerged and changed over time. Although there are growing efforts to address these gaps (see Section 'New directions'), institutional analysis generally appears to facilitate relatively static empirical research on the impacts of variables and create challenges for analysing the coevolution of institutions and social-ecological processes.

Institutional analysis has also been criticised for its emphasis on analysing cooperation at the expense of other social processes and mechanisms premised on values, conflict or power dynamics

\section{Case study 22.1: Environmental governance of Mexican community fisheries}

Basurto and Ostrom (2009) provide an illustrative example of how institutional analysis can be used to support research on environmental governance. Their paper begins by arguing that fishers will elect to invest in developing rules when presented with favourable incentives, and then draws on previous research to highlight several attributes of the resource and fishing community that are likely to influence the nature of these incentives. Three benthic fisheries in Mexico were used to evaluate the conditions in which groups are successful in self-organising to govern the use of local resources. As predicted, the two cases in which groups had strong local leadership, high levels of social capital and high levels of dependence on the resource in addition to several favourable attributes of the resource system had successfully self-organised to develop new institutions, whereas the one case that lacked many of these conditions failed to self-organise.

The authors extended their analysis to examine the robustness of the governance systems developed by the successful communities using Ostrom's (1990) design principles. They found that, although both communities had successfully self-organised to develop rules, only one of these systems proved robust to an external 
(Agrawal 2003; Clement 2010). In fact, several decentralisation initiatives meant to promote cooperation at the local level have failed to achieve their intended objectives precisely because powerful actors exploit their knowledge, resources and authority to retain control over the governance of natural resources (Blaikie 2006; Ribot, Agrawal, and Larson 2006). Similarly, important challenges remain with respect to integrating institutional and ecological theory to foster a truly interdisciplinary understanding of the sustainability of SES (Epstein et al. 2013). Finally, institutional analysis has struggled immensely in its attempt to manage trade-offs between flexibility to allow scholars to adjust their approach to different contexts and methods and consistency to support cross-case comparison and empirical synthesis. In particular, it has thus far failed to provide clear guidelines for measuring core concepts and variables (Thiel, Adamseged, and Baake 2015; Partelow 2018; Schlager and Cox 2018), resulting in a patchwork of empirical findings that are difficult to integrate and compare.

\section{Resource implications}

Institutional analysis does not in and of itself require significant resources in terms of materials, technology or financing to undertake meaningful and impactful research on sustainable environmental governance. In practice, knowledge of the language of institutional analysis is important to understand its core theories, therefore training (see Section 'Key readings') is often a critical precondition for effectively engaging with institutional research. Furthermore, certain methods used for institutional analysis, such as agent-based models (Schoon et al. 2014) and dynamic multi-player experimental environments (Janssen et al. 2010), require access to relatively advanced hardware and software packages and skills in computer programming. In contrast, an ethnographic study may require a significant investment of

shock. Whereas the governance system employed by the Seri community was characterised by all eight design principles, the Peñasco community lacked external recognition of their rights to self-organise and a system of nested governance. As a result, when the Peñasco community was faced with a rapid influx of fishers from other communities, they lacked the legal authority and adequate resources to exclude them, resulting in the rapid depletion of the resource.

Basurto and Ostrom (2009) exemplify a number of defining characteristics of institutional analysis and its approach to the study of the sustainability of SES, although it is important to note that these characteristics can vary widely across different methods or studies. Nonetheless, the paper begins by clearly specifying the action situation(s) that it aims to investigate (rule change) and considers how attributes of the resource system and actors are likely to influence the incentives that groups face in that situation. The empirical analysis, meanwhile, allows them to test their hypotheses and specify the combinations of attributes that appear to give rise to outcomes.

Finally, the design principles analysis aggregates several action situations to explore how the presence or absence of a suite of principles affects robustness of the system to shocks. In fact, aggregation of multiple action situations is implicit to many institutional studies that seek to understand the relationships between variables and a range of social and ecological outcomes. 
time and financial resources to build trust with resource-dependent communities to reveal the important, but often unwritten, rules that structure human interactions with the environment (Acheson 2003).

\section{New directions}

The field of institutional analysis continues to evolve swiftly to address many of the gaps discussed above and respond to current needs for research on the sustainability of SES. These efforts include broadening the diversity of cases that inform institutional theory; characterising and analysing relationships among actors, the environment and decision-making arenas at multiple scales; and developing tools to support empirical research and synthesis.

Several research programmes have been developed in recent years in response to critiques of the relatively limited range of cases and outcomes that inform institutional analysis. Empirical studies, for instance, are increasingly analysing relationships between institutions and multiple social and ecological outcomes to identify opportunities for often elusive 'winwin' outcomes (Persha, Agrawal, and Chhatre 2011; Cinner et al. 2012). Others, meanwhile, have explored the extent to which principles derived from the study of the small-scale community-based governance of natural resources might apply to cases involving communities facing significant external socio-economic and ecological disturbances (Brondizio, Ostrom, and Young 2009; Villamayor-Tomas and García-López 2017), large-scale resource systems (Fleischman et al. 2014), pollution (Epstein et al. 2014b) and energy systems (Bauwens, Gotchev, and Holstenkamp 2016). As efforts continue to expand the diversity of cases and outcomes, there is a great opportunity to gain traction on important questions concerning contextually explicit institutional design.

Institutional analysis has also been influenced by developments in network theory to analyse the network structures and processes that underlie sustainable environmental governance. First, social-ecological networks are increasingly being used as a tool to clarify the structure of environmental problems to develop insights for addressing them. This line of research generally highlights the importance of developing mechanisms to coordinate the governance of interlinked resources (Bodin 2017). Second, networks among multiple arenas of decision-making are used to analyse the development and implementation of environmental governance systems. The ecology of games (Lubell 2013) and the networks of action situation approaches (McGinnis 2011) facilitate efforts to develop insights about how institutions and patterns of behaviour emerge from networks of interdependent decisions.

Finally, several tools have been developed that aim to contribute to the development of knowledge by formalising our understanding of concepts to facilitate the comparison and integration of research findings. The Social-Ecological Systems Meta-Analysis Database (SESMAD) project, for instance, has operationalised many of the variables used in previous studies and used them to formally express a number of environmental governance theories (Cox 2014; Cox et al. 2016). The grammar of institutions has also been adapted in recent years to provide a tool to systematically characterise institutional arrangements and study institutional change over time (Ostrom and Basurto 2011). Further initiatives, meanwhile, have offered conceptual clarifications on the concept of institutional fit (Epstein et al. 2015) and begun to formalise the study of power in institutional research (Epstein et al. 2014a; Morrison et al. 2017). 


\section{Key readings}

Crawford, S.E., and E. Ostrom. 1995. 'A Grammar of Institutions.' American Political Science Review 89(3): 582-600.

McGinnis, M.D. 2011. 'An Introduction to IAD and the Language of the Ostrom Workshop: A Simple Guide to a Complex Framework.' Policy Studies Journal 39(1): 169-183.

Ostrom, E. 2005. Understanding Institutional Diversity. Princeton: Princeton University Press.

Ostrom, E. 2007. 'A Diagnostic Approach for Going Beyond Panaceas.' Proceedings of the National Academy of Sciences 104(39): 15181-15187.

Thiel, A., M.E. Adamseged, and C. Baake. 2015. 'Evaluating an Instrument for Institutional Crafting: How Ostrom's Social-Ecological Systems Framework is Applied.' Environmental Science and Policy 53: 152-164.

\section{Acknowledgements}

The authors would like to thank the Ostrom Workshop at Indiana University where they received training in understanding institutions. Michael Schoon would also like to thank the Center for Behavior, Institutions and the Environment at Arizona State University and the support and insight of his colleagues there.

\section{References}

Acheson, J.M. 2003. Capturing the Commons: Devising Institutions to Manage the Maine Lobster Industry. Lebanon: University Press of New England.

Agrawal, A. 2003. 'Sustainable Governance of Common Pool Resources: Context, Methods, and Politics.' Annual Review of Anthropology 32(1): 243-262.

Agrawal, A., and S. Goyal. 2001. 'Group Size and Collective Action.' Comparative Political Studies 34: 63-93.

Anderies, J.M. 2000. 'On Modeling Human Behavior and Institutions in Simple Ecological Economic Systems.' Ecological Economics 35(3): 393-412.

Anderies, J.M., M.A. Janssen, and E. Ostrom. 2004. 'A Framework to Analyze the Robustness of Social-Ecological Systems from an Institutional Perspective.' Ecology and Society 9(1): 18.

Andersson, K., and A. Agrawal. 2011. 'Inequalities, Institutions, and Forest Commons.' Global Environmental Change 21(3): 866-875.

Baggio, J., A. Barnett, I. Perez-Ibarra, U. Brady, E. Ratajczyk, N. Rollins, C. Rubiños, H. Shin, D. Yu, and R. Aggarwal. 2016. 'Explaining Success and Failure in the Commons: The Configural Nature of Ostrom's Institutional Design Principles.' International Journal of the Commons 10(2): 417-439.

Basurto, X., and E. Ostrom. 2009. 'Beyond the Tragedy of the Commons.' Economia delle Fonti di Energia e dell'Ambiente LII(1): 35-60.

Bauwens, T., B. Gotchev, and L. Holstenkamp. 2016. 'What Drives the Development of Community Energy in Europe? The Case of Wind Power Cooperatives.' Energy Research and Social Science 13: 136-147.

Berkes, F., T.P. Hughes, R.S. Steneck, J.A. Wilson, D.R. Bellwood, B. Crona, C. Folke et al. 2006. 'Globalization, Roving Bandits, and Marine Resources.' Science 311: 1557-1558.

Blaikie, P. 2006. 'Is Small Really Beautiful? Community-based Natural Resource Management in Malawi and Botswana.' World Development 34: 1942-1957.

Bodin, Ö. 2017. 'Collaborative Environmental Governance: Achieving Collective Action in Social-Ecological Systems.' Science 357(6352): eaan1114.

Bodin, Ö., B. Crona, M. Thyresson, A.L. Golz, and M. Tengö. 2014. 'Conservation Success as a Function of Good Alignment of Social and Ecological Structures and Processes.' Conservation Biology 28(5): 1371-1379.

Brondizio, E.S., E. Ostrom, and O.R. Young. 2009. 'Connectivity and the Governance of Multilevel Social-Ecological Systems: The Role of Social Capital.' Annual Review of Environment and Resources 34: 253-278. 
Cárdenas, J-C., and E. Ostrom. 2004. 'What Do People Bring into the Game? Experiments in the Field about Cooperation in the Commons.' Agricultural Systems 82(3): 307-326.

Cárdenas, J-C., J. Stranlund, and C. Willis. 2000. 'Local Environmental Control and Institutional Crowding-Out.' World Development 28(10): 1719-1733.

Chhatre, A., and A. Agrawal. 2009. 'Trade-offs and Synergies Between Carbon Storage and Livelihood Benefits from Forest Commons.' Proceedings of the National Academy of Sciences 106(42): 17667-17670.

Cinner, J.E., T.R. McClanahan, M.A. MacNeil, N.A.J. Graham, T.M. Daw, A. Mukminin, D.A. Feary et al. 2012. 'Comanagement of Coral Reef Social-Ecological Systems.' Proceedings of the National Academy of Sciences 109: 5219-5222.

Clement, F. 2010. 'Analysing Decentralised Natural Resource Governance: Proposition for a "Politicised” Institutional Analysis and Development Framework.' Policy Sciences 43: 129-156.

Cole, D.H., G. Epstein, and M.D. McGinnis. 2019. 'Combining the IAD and SES Frameworks.' International Journal of the Commons 13(1): 244-275.

Cox, M. 2014. 'Understanding Large Social-Ecological Systems: Introducing the SESMAD Project.' International Journal of the Commons 8(2): 265-276.

Cox, M., G. Arnold, and S. Villamayor-Tomas. 2010. 'A Review of Design Principles for Community-based Natural Resource Management.' Ecology and Society 15(4): 38.

Cox, M., S. Villamayor-Tomas, G. Epstein, L. Evans, N.C. Ban, F. Fleischman, M. Nenadovic, and G. Garcia-Lopez. 2016. 'Synthesizing Theories of Natural Resource Management and Governance.' Global Environmental Change 39: 45-56.

Crawford, S.E.S., and E. Ostrom. 1995. 'A Grammar of Institutions.' The American Political Science Review 89(3): 582-600.

DeCaro, D.A., M.A. Janssen, and A. Lee. 2015. 'Synergistic Effects of Voting and Enforcement on Internalized Motivation to Cooperate in a Resource Dilemma.' Judgment and Decision Making 10: 511-537.

Dietz, T. 2005. 'The Darwinian Trope in the Drama of the Commons: Variations on Some Themes by the Ostroms.' Journal of Economic Behavior and Organization 57: 205-225.

Epstein, G., A. Bennett, R. Gruby, L. Acton, and M. Nenadovic. 2014a. 'Understanding Power with the Social-Ecological Systems Framework.' In Understanding Society and Natural Resources: Forging New Strands of Integration Across the Social Sciences, edited by M. Manfredo, J. Vaske, A. Rechkemmer, and E. Duke, 111-135. New York: Springer.

Epstein, G., I. Pérez, M. Schoon, and C.L. Meek. 2014b. 'Governing the Invisible Commons: Ozone Regulation and the Montreal Protocol.' International Journal of the Commons 8(2): 337-360.

Epstein, G., J. Pittman, S.M. Alexander, S. Berdej, T. Dyck, U. Kreitmair, K.J. Raithwell, S. Villamayor-Tomas, J. Vogt, and D. Armitage. 2015. 'Institutional Fit and the Sustainability of SocialEcological Systems.' Current Opinion in Environmental Sustainability 14(June): 34-40.

Epstein, G., J.M. Vogt, S.K. Mincey, M. Cox, and B. Fischer. 2013. 'Missing Ecology: Integrating Ecological Perspectives with the Social-Ecological System Framework.' International Journal of the Commons 7(2): 432-453.

Fleischman, F.D., N.C. Ban, L.S. Evans, G. Epstein, G. Garcia-Lopez, and S. Villamayor-Tomas. 2014. 'Governing Large-scale Social-Ecological Systems: Lessons from Five Cases.' International Journal of the Commons 8(2): 428-456.

Galaz, V., P. Olsson, T. Hahn, C. Folke, and U. Svedin. 2008. 'The Problem of Fit among Biophysical Systems, Environmental and Resource Regimes, and Broader Governance Systems: Insights and Emerging Challenges.' In Institutions and Environmental Change - Principal Findings, Applications, and Research Frontiers, edited by O.R. Young, L.A. King, and H. Schröder, 147-182. Cambridge: MIT Press. www.stockholmresilience.org/publications/artiklar/2009-12-22-the-problem-offit-between-governance-systems-and-environmental-regimes.html.

Gelcich, S., R. Guzman, C. Rodríguez-Sickert, J.C. Castilla, and J.C. Cárdenas. 2013. 'Exploring External Validity of Common Pool Resource Experiments: Insights from Artisanal Benthic Fisheries in Chile.' Ecology and Society 18(3): 2.

Gibson, C.C., M.A. McKean, and E. Ostrom, eds. 2000. People and Forests: Communities, Institutions, and Governance. Cambridge: MIT Press.

Gutiérrez, N.L., R. Hilborn, and O. Defeo. 2011. 'Leadership, Social Capital and Incentives Promote Successful Fisheries.' Nature 470(7334): 386.

Hagedorn, K. 2008. 'Particular Requirements for Institutional Analysis in Nature-related Sectors.' European Review of Agricultural Economics 35(3): 357-384. 
Hall, P.A., and R.C.R. Taylor. 1996. 'Political Science and the Three New Institutionalisms.' Political Studies 44: 936-957.

Hardin, G. 1968. 'The Tragedy of the Commons.' Science 162: 1243-1248.

Heikkila, T., and C.M. Weible. 2018. 'A Semiautomated Approach to Analyzing Polycentricity.' Environmental Policy and Governance 28(4): 308-318.

Hodgson, G.M. 1998. 'The Approach of Institutional Economics.' Journal of Economic Literature 36(1): $166-192$.

Janssen, M.A. 2013. 'The Role of Information in Governing the Commons: Experimental Results.' Ecology and Society 18(4): 4.

Janssen, M.A., R. Holahan, A. Lee, and E. Ostrom. 2010. 'Lab Experiments for the Study of Social-Ecological Systems.' Science 328(5978): 613-617.

Jones, R., C. Rigg, and E. Pinkerton. 2017. 'Strategies for Assertion of Conservation and Local Management Rights: A Haida Gwaii Herring Story.’ Marine Policy 80: 154-167.

Kiser, LL., and E. Ostrom. 1982. 'The Three Worlds of Action: A Metatheoretical Synthesis of Institutional Approaches.' In Polycentric Games and Institutions: Readings from the Workshop in Political Theory and Policy Analysis, edited by M.D. McGinnis, 56-89. Ann Arbor: University of Michigan Press.

Lien, A.M., E. Schlager, and A. Lona. 2018. 'Using Institutional Grammar to Improve Understanding of the Form and Function of Payment for Ecosystem Services Programs.' Ecosystem Services 31: 21-31.

Lindahl, T., O. Bodin, and M. Tengö. 2015. 'Governing Complex Commons - The Role of Communication for Experimental Learning and Coordinated Management.' Ecological Economics 111: 111-120.

Lubell, M. 2013. 'Governing Institutional Complexity: The Ecology of Games Framework.' Policy Studies Journal 41: 537-559.

McGinnis, M.D. 2011. 'An Introduction to IAD and the Language of the Ostrom Workshop: A Simple Guide to a Complex Framework.' Policy Studies Journal 39(1): 169-183.

McGinnis, M.D., and E. Ostrom. 2014. 'Social-Ecological System Framework: Initial Changes and Continuing Challenges.' Ecology and Society 19(2): 30.

Mitchell, W.C. 1988. 'Virginia, Rochester, and Bloomington: Twenty-Five Years of Public Choice and Political Science.' Public Choice 56: 101-119.

Monroy-Sais, S., A. Castillo, E. García-Frapolli, and G. Ibarra-Manríquez. 2016. 'Ecological Variability and Rule-Making Processes for Forest Management Institutions: A Social-Ecological Case Study in the Jalisco Coast, Mexico.' International Journal of the Commons 10(2): 1144-1171.

Morrison, T.H., W.N. Adger, K. Brown, M.C. Lemos, D. Huitema, and T.P. Hughes. 2017. 'Mitigation and Adaptation in Polycentric Systems: Sources of Power in the Pursuit of Collective Goals.' Wiley Interdisciplinary Reviews: Climate Change 8(5): e479.

Ostrom, E. 1990. Governing the Commons. New York: Cambridge University Press.

Ostrom, E. 1998. 'A Behavioral Approach to the Rational Choice Theory of Collective Action: Presidential Address, American Political Science Association 1997.' The American Political Science Review 92: $1-22$.

Ostrom, E. 2005. Understanding Institutional Diversity. Princeton: Princeton University Press.

Ostrom, E. 2007. 'A Diagnostic Approach for Going Beyond Panaceas.' Proceedings of the National Academy of Sciences 104(39): 15181-15187.

Ostrom, E., and X. Basurto. 2011. 'Crafting Analytical Tools to Study Institutional Change.' Journal of Institutional Economics 7(Special Issue 3): 317-343.

Ostrom, E., R. Gardner, and J. Walker. 1994. Rules, Games and Common Pool Resources. Ann Arbor: Michigan University Press.

Ostrom, E., R.B. Parks, and P.W. Gordon. 1973. 'Do We Really Want to Consolidate Urban Police Forces? A Reappraisal of Some Old Assertions.' Public Administration Review 33(5): 423-432.

Ostrom, V., C.M. Tiebout, and R. Warren. 1961. 'The Organization of Government in Metropolitan Areas: A Theoretical Inquiry.' The American Political Science Review 55: 831-842.

Partelow, S. 2018. 'A Review of the Social-Ecological Systems Framework: Applications, Methods, Modifications, and Challenges.' Ecology and Society 23(4): 36.

Persha, L., A. Agrawal, and A. Chhatre. 2011. 'Social and Ecological Synergy: Local Rulemaking, Forest Livelihoods, and Biodiversity Conservation.' Science 331: 1606-1608.

Poteete, A.R., M.A. Janssen, and E. Ostrom. 2010. Working Together: Collective Action, the Commons, and Multiple Methods in Practice. Princeton: Princeton University Press.

Ribot, J.C., A. Agrawal, and A.M. Larson. 2006. 'Recentralizing While Decentralizing: How National Governments Reappropriate Forest Resources.' World Development 34: 1864-1886. 
Schlager, E. 1999. 'A Comparison of Frameworks, Theories, and Models of Policy Processes.' Theories of the Policy Process 1: 233-260.

Schlager, E., W. Blomquist, and S.Y. Tang. 1994. 'Mobile Flows, Storage, and Self-Organized Institutions for Governing Common-pool Resources.' Land Economics 70: 294-317.

Schlager, E., and M. Cox. 2018. 'The IAD Framework and the SES Framework: An Introduction and Assessment of the Ostrom Workshop Frameworks.' In Theories of the Policy Process, edited by C.M. Weible and P.A. Sabatier, 225-262. Abingdon: Routledge.

Schill, C., T. Lindahl, and A-S. Crépin. 2015. 'Collective Action and the Risk of Ecosystem Regime Shifts: Insights from a Laboratory Experiment.' Ecology and Society 20(1): 48.

Schoon, M., J.A. Baggio, K.R. Salau, and M. Janssen. 2014. 'Insights for Managers from Modeling Species Interactions across Multiple Scales in an Idealized Landscape.' Environmental Modelling and Software 54: 53-59.

Shepsle, K.A. 2006. 'Rational Choice Institutionalism.' In The Oxford Handbook of Political Institutions, edited by R.A. Rhodes, S.A. Binder, and B.A. Rockman. Oxford: Oxford University Press.

Siddiki, S, X. Basurto, and C.M. Weible. 2012. 'Using the Institutional Grammar Tool to Understand Regulatory Compliance: The Case of Colorado Aquaculture.' Regulation \& Governance 6(2): 167-188.

Siddiki, S., C.M. Weible, X. Basurto, and J. Calanni. 2011. 'Dissecting Policy Designs: An Application of the Institutional Grammar Tool.' Policy Studies Journal 39(1): 79-103.

Thiel, A., M.E. Adamseged, and C. Baake. 2015. 'Evaluating an Instrument for Institutional Crafting: How Ostrom's Social-Ecological Systems Framework is Applied.' Environmental Science and Policy 53: $152-164$.

Van Laerhoven, F., and E. Ostrom. 2007. 'Traditions and Trends in the Study of the Commons.' International Journal of the Commons 1: 3-28.

Vatn, A. 2005. 'Rationality, Institutions and Environmental Policy.' Ecological Economics 55(2): 203-217.

Villamayor-Tomas, S., and G. García-López. 2017. 'The Influence of Community-based Resource Management Institutions on Adaptation Capacity: A Large-N Study of Farmer Responses to Climate and Global Market Disturbances.' Global Environmental Change 47: 153-166.

Villamayor-Tomas, S., P. Grundmann, G. Epstein, T. Evans, and C. Kimmich. 2015. 'The WaterEnergy-Food Security Nexus Through the Lenses of the Value Chain and IAD Frameworks.' Water Alternatives 8(1): 735-755.

Young, O.R. 2002. The Institutional Dimensions of Environmental Change: Fit, Interplay, and Scale. Cambridge: MIT Press. 